
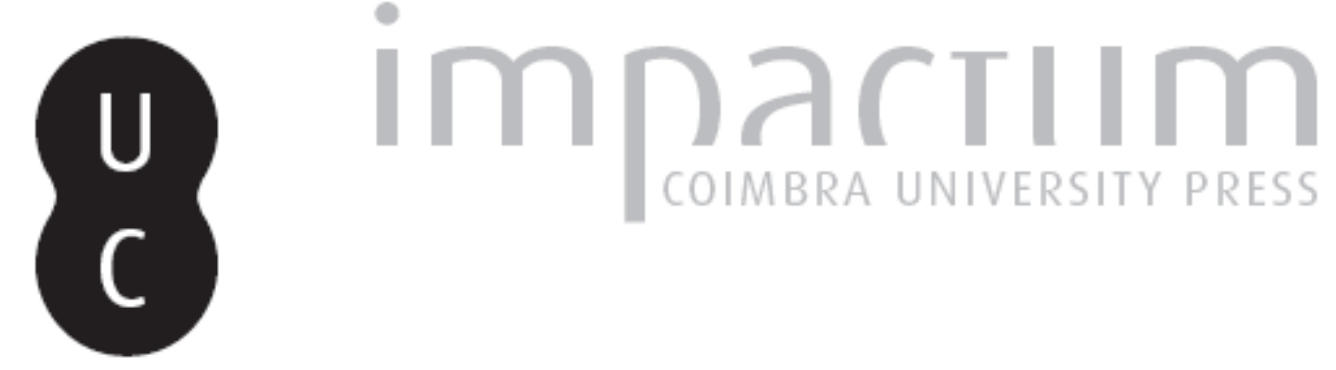

\title{
[Recensão a] Obras Completas de José Acúrsio das Neves, vol. 1: «Historia Geral da Invasão dos Franceses em Portugal e da Restauração deste Reino», tomos I e II. Estudos introdutórios de António Almodovar e Armando Castro
}
Autor(es):
Vargues, Isabel Nobre

Publicado por: Imprensa da Universidade de Coimbra

URL

persistente:

URI:http://hdl.handle.net/10316.2/43846

DOI:

DOI:https://doi.org/10.14195/2183-8925_6_18

\section{Accessed : $\quad$ 26-Apr-2023 15:01:49}

A navegação consulta e descarregamento dos títulos inseridos nas Bibliotecas Digitais UC Digitalis, UC Pombalina e UC Impactum, pressupõem a aceitação plena e sem reservas dos Termos e Condições de Uso destas Bibliotecas Digitais, disponíveis em https://digitalis.uc.pt/pt-pt/termos.

Conforme exposto nos referidos Termos e Condições de Uso, o descarregamento de títulos de acesso restrito requer uma licença válida de autorização devendo o utilizador aceder ao(s) documento(s) a partir de um endereço de IP da instituição detentora da supramencionada licença.

Ao utilizador é apenas permitido o descarregamento para uso pessoal, pelo que o emprego do(s) título(s) descarregado(s) para outro fim, designadamente comercial, carece de autorização do respetivo autor ou editor da obra.

Na medida em que todas as obras da UC Digitalis se encontram protegidas pelo Código do Direito de Autor e Direitos Conexos e demais legislação aplicável, toda a cópia, parcial ou total, deste documento, nos casos em que é legalmente admitida, deverá conter ou fazer-se acompanhar por este aviso.

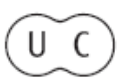




\section{REVISTA DE HISTORIA DAS IDEIAS 6}

\section{. \\ REVOLTAS E REVOLUCOEES}

*

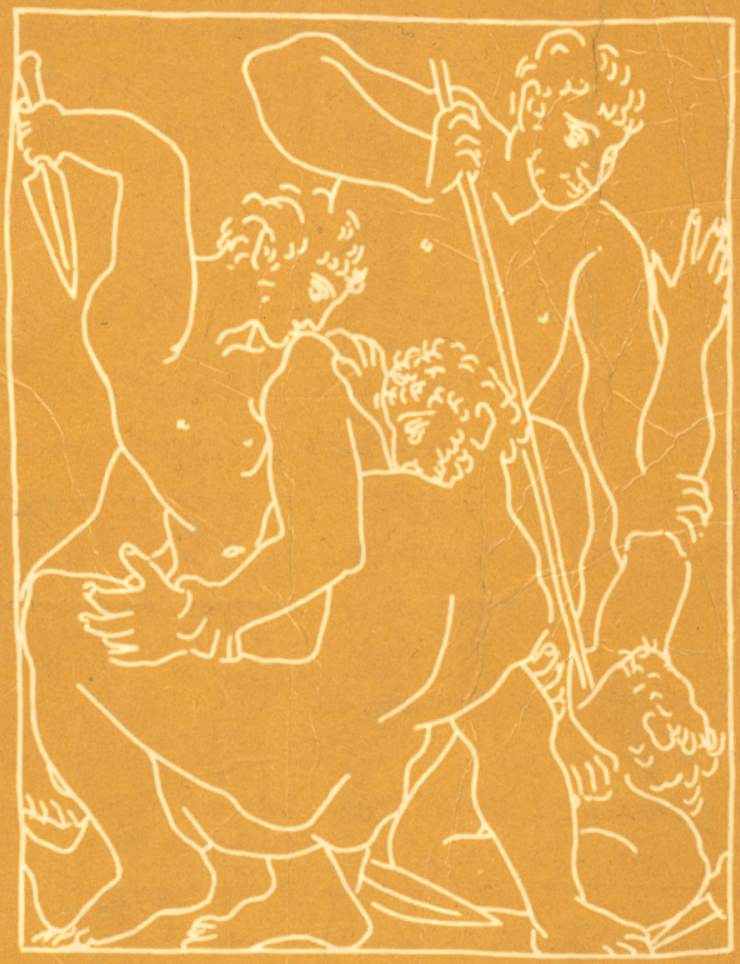

INSTITUTO DE HISTORIA E TEORIA DAS IDEIAS FACULDADE DE LETRAS 
Obras Completas de José Acúrsio das Neves, vol. 1: «História Geral da Invasão dos Franceses em Portugal e da Restauração deste Reino», tomos I e II. Estudos introdutórios de António Almodovar e Armando Castro, Porto, Edições Afrontamento, 1984, 448 pp.

Já não é sem tempo que as editoras portuguesas começam a lançar os seus interesses para a necessidade de reeditar obras clássicas da nossa história e particularmente dos séculos XVIII e XIX. Desde a publicação de memórias e de estudos portugueses (veja-se, por exemplo, a Colecção Arquivos da editora Assírio e Alvim, que conta, entre os números já publicados, com as Memórias da vida de José Liberato Freire de Carvalho), à Série Portugal e os Estrangeiros que em boa hora a Biblioteca Nacional empreendeu, e a algumas colecções lançadas pela INCM, estas novas edições, que há cerca de alguns anos começaram a ser publicadas, merecem ser aplaudidas não só porque muitas vezes os seus textos são de leitura e acesso difíceis como, por outro lado, já se não encontram facilmente nas bibliotecas, e, essencialmente, porque é urgente revivificar a historiografia nacional.

O exemplo escolhido pelas Edições Afrontamento (e patrocinado pelo Instituto Português do Livro) é uma satisfação tanto para o investigador do século XIX, como para o leitor que não pretende uma especialização, mas sim o conhecimento de alguns factos da nossa história que mais viva se torna quando nos é narrada por alguém que presenciou os acontecimentos. Senão vejamos: a anteceder este volume I das Obras Completas de José Acúrsio das Neves, explicam-se os motivos que levaram à presente publicação e o critério que presidiu à ordenação das Obras Completas; segue-se, depois, uma nota biobibliográfica, algumas obras que existem sobre José Acúrsio das Neves e ainda a enriquecê-la, dois estudos.

O primeiro, da autoria de António Almodovar, tem como título «O pensamento político-económico de José Acúrsio das Neves: uma proposta de leitura", e o segundo, cujo autor é Armando Castro, intitula-se "José Acúrsio das Neves, um doutrinador da sua época historicamente atrasado". São sem dúvida dois bons contributos para se alargar o conhecimento sobre José Acúrsio das Neves, autor que a historiografia tradicional nos habituou a ver unicamente sob dois prismas: o político contra-revolucionário ou/e o economista, desligando estas e outras facetas do seu pensamento.

A História não pode ser apaixonada mas J. Acúrsio das Neves é um vulto apaixonante que não pode passar desperce- 
bido a quem se debruce sobre o nosso passado na primeira metade do século XIX e na implantação do liberalismo.

$\mathrm{Se}$ o texto de A. Almodovar nos alerta para uma nova leitura que urge fazer sobre Acúrsio das Neves, o de A. Castro não é menos importante pois que, partindo daquele, apresenta toda uma análise crítica da historiografia disponível sobre Acúrsio das Neves, tratando com mestria aquilo que chama de "herança doutrinal» de José Acúrsio das Neves.

Vejamos agora a "História Geral da Invasão dos Franceses em Portugal e da Restauração deste Reino". A obra terá sido escrita muito provavelmente entre 1809 e 1811 (em 5 volumes) em plena época de ocupação francesa. Invasâo e Restauração foram, aliás, temas indissociáveis e muito explorados na imprensa portuguesa, particularmente entre 1807 e 12 . Não têm conta as múltiplas obras que se escreveram em Portugal sobre eles, mas a "História Geral da Invasão dos Franceses» de Acúrsio das Neves é, talvez, uma das narrativas mais completas e por isso a mais citada por quem estuda essa época. Acúrsio das Neves não é um historiador no sentido corrente da palavra (o seu registo é mais próprio de um memorialista) mas isso não o impede de nos oferecer um relato muito curioso sobre o tema das invasões francesas em Portugal: no tomo I, em 25 capítulos, o A. desenvolve algumas ideias sobre os antecedentes das invasões (o jogo diplomático entre as potências europeias desde finais do século XVIII e particularmente o conflito que opôs a França à Inglaterra; a entrada dos países da Península Ibérica nesse conflito; a política de neutralidade ensaiada pelo governo português), e a invasão propriamente dita (a declaração de guerra a Portugal; a partida de D. João VI e da Corte para o Brasil; o governo de Junot em Portugal; os inícios da reacção popular à ocupação; e a presença das tropas francesas no país em 1807).

No tomo II, em 17 capítulos, continua a descrição dos episódios talvez mais representativos que as invasões e o governo de Junot tiveram em Portugal: as determinaçōes legais que recaíram sobre o povo português; os partidários dos franceses; os levantamentos que, um pouco por todo o país, começam a surtir efeito; o reavivar de um dos temas favoritos do nosso imaginário - o sebastianismo; o policiamento e a administração da Justiça pelo novo Intendente Lagarde; a deputação portuguesa a Baiona em 1808; a conjugação de esforços entre Murat e Junot na ocupação de Espanha e de Portugal.

Por este enunciado temático dos dois volumes iniciais da «História Geral da Invasão dos Franceses em Portugal e 
da Restauração deste Reino", podemos ver o interesse que desperta a sua leitura.

Fazemos votos para que as Obras Completas de José Acúrsio das Neves continuem pois a sair regularmente.

Isabel Nobre Vargues

G. F. Sacarrão - A Biologia do Egoismo, Lisboa, Publicações Europa-América, s. d., 162 pp. (p. 105).

"A biologia dirá sempre o que se quiser que ela diga»

$\mathrm{Na}$ produção nacional científico-político-ideológica mais recente, destacamos esta obra de G. F. Sacarrão, professor catedrático de Zoologia e Antropologia na Faculdade de Ciências da Universidade Clássica de Lisboa.

Trata-se de um ensaio crítico de fácil leitura sobre a sociobiologia, suas ambições epistemológicas e prolongamentos ético-políticos - tema largamente debatido e divulgado desde os finais da década de 70 que continua a chamar a atenção dos intelectuais interessados pelos bastidores teórico-sociológicos das práticas e projectos políticos.

Em 1975 Edward O. Wilson publicou uma síntese monumental sobre as bases biológicas das sociedades animais (e humanas) intitulada Sociobiology. The new synthesis. Constituída na base dos progressos da Genética das populações, da Ecologia evolutiva e da Etologia, esta nova disciplina tem por objecto o comportamento do animal (e do homem) em sociedade. Dos componentes em jogo, o genético ou hereditário, o ecológico ou ambiental e o etológico ou comportamental, é o último que ocupa o lugar central nas investigações sociobiológicas.

$\mathrm{Na}$ perspectiva desta disciplina o princípio determinante do comportamento do qual resulta a estrutura e funcionamento das sociedades animais (e humanas) é o "egoísmo genético": "tudo o que o organismo faz visa a propagação dos seus próprios genes, em fazer com que os 'melhores' deles passem à geração seguinte» (p. 31). 0 indivíduo ou o organismo é o "meio" de que os genes se servem para cumprir esta finalidade; nele, os genes animados duma força vital lutam entre si e dessa "corrida para o sucesso" resulta ne- 